\title{
Apakah Pengkayaan Lingkungan Berpengaruh terhadap Ingatan Spasial pada Tikus Jantan dan Betina?
}

\author{
Sri Kusrohmaniah', Rozainee Khairudin ${ }^{2}$, E Asmawati binti Desa ${ }^{3}$ \\ ${ }^{1}$ Fakultas Psikologi Universitas Gadjah Mada \\ ${ }^{2,3}$ Fakulti Sains Sosial dan Kemanusiaan Universiti Kebangsaan Malaysia
}

\begin{abstract}
Female and male rats use different landmarks to find foods in the radial arm maze. The aim of this research was to test the effect of environmental enrichment on spatial memory of male and female rats. Twenty two male and 22 female Wistar rats (Rattus novergicus) were allocated into eight groups. Spatial memory were measured after 60 days of environmental enrichment. It was hypothesized that rats in the environmentally enriched groups had better spatial memory. Analysis was done using SPANOVA (Mixed Design Anova). It was found that sex had an effect on spatial memory.
\end{abstract}

Keywords: brain; environmental enrichment; gonad hormones; rats; spatial memory

\begin{abstract}
Abstrak. Tikus jantan dan betina menggunakan landmark (penanda ligkungan) yang berbeda dalam menemukan makanan pada radial arm maze. Penelitian ini bertujuan menguji pengaruh pengkayaan lingkungan terhadap ingatan spasial pada tikus jantan dan betina. Duapuluh dua ekor tikus jantan dan 22 ekor tikus betina galur Wistar terbagi dalam delapan kelompok diukur ingatan spasialnya setelah mendapat pengkayaan lingkungan selama 60 hari. Hipotesis yang diajukan dalam penelitian ini bahwa kelompok yang mendapat pengkayaan lingkungan memiliki ingatan spasial lebih baik, diuji dengan menggunakan SPANOVA (ANOVA Mixed Design). Hasil analisis menunjukkan tidak ada interaksi antara pengkayaan lingkungan dan jenis kelamin terhadap ingatan spasial. Tidak ada pengaruh perlakuan terhadap ingatan spasial. Ada pengaruh jenis kelamin terhadap ingatan spasial.
\end{abstract}

Kata kunci: hormon gonad; ingatan spasial; otak; pengkayaan lingkungan; tikus

Ingatan spasial adalah kemampuan mengingat lokasi suatu objek, tempat, ruangan, navigasi, dan arah. Mengingat lokasi objek ini membutuhkan validitas ekologi yang baik. Ingatan spasial adalah ingatan yang berkaitan dengan ruang bidang, ingatan yang mengarahkan seseorang menuju suatu lokasi atau tempat suatu benda berada, kedudukan diri, atau lokasi suatu kota atau daerah, ingatan ruang spasial membentuk peta kognitif

\footnotetext{
${ }^{1}$ Korespondensi mengenai artikel ini dapat melalui: koes_psi@ugm.ac.id
}

(Chalfonte, Verfaellie, Johnson, \& Reiss, 1996; Guyton \& Hall, 2001; Pinel, 2009). Ingatan ruang spasial juga meliputi detail figural, komposisi spasial, dan lokasi spasial (Baxendale, Thompson, \& Paesschen, 1998). Menurut pendapat O'Keefe \& Nadel (1980), ingatan ruang spasial dikonseptualisasikan sebagai subtipe dari ingatan episode karena adanya penyimpanan informasi dalam bingkai 
spatio-temporal, dan ingatan ruang spasial tergantung pada hipokampus.

Sistem ingatan ruang spasial pada manusia dan hewan adalah mirip. Adanya kesamaan sistem ingatan pada manusia dan hewan diperoleh dari penelitian yang juga sudah lama dilakukan oleh Dale (1987), yang hasilnya adalah bahwa proses ingatan pada hewan adalah analog pada manusia, yaitu bahwa model untuk mengingat objek dan menyusun informasi adalah sama. Analogi antara proses ingatan pada hewan dan pada manusia yang rumit adalah pada adanya variabel serial. Perbedaan ingatan ruang spasial pada hewan dan manusia adalah manusia dapat mengkomunikasikan tentang suatu lokasi kepada orang lain sedangkan pada hewan tidak.

Jenis kelamin antara laki-laki dan perempuan berperanan terhadap fungsi kognitif, antara lain kemampuan untuk belajar, menyimpan, dan mengingat informasi, bisa berbeda karena usia dan perbedaan jenis kelamin. Pola-pola kemampuan kognitif tampaknya tergantung kepada perubahan atau kadar hormon steroid. Dari berbagai penelitian menemukan bahwa hormon steroid, gonad, dan adrenal, berpengaruh terhadap fungsi kognitif. Satu studi menunjukkan bahwa estrogen (yang langsung disekresikan atau berasal dari androgen) dan glukokortikoid (kortisol pada manusia dan kortikosteron pada tikus) memberi efek pemrograman pada kognisi selama periode perinatal yang kemudian diekspresikan pada usia dewasa (Ziegler \& Thornton, 2010).

Perbedaan jenis kelamin dalam penggunaan isyarat spasial tampaknya khas spesies mamalia poligami dimana perempuan dan laki-laki berbeda dalam penggunaan ruang. Dalam penelitian sebelumnya ditemukan bahwa tikus jantan dan betina berbeda dalam kemampuan mengingat spasial disebabkan karena adanya perbedaan tanda-tanda yang dipakai untuk mengingat suatu lokasi. Penelitian pada tikus menunjukkan bahwa tikus jantan poligami akan menggunakan isyarat arah dan jarak dalam menemukan suatu lokasi, sedangkan tikus betina menggunakan isyarat benda-benda yang ada di dekatnya sebagai bantuan untuk menemukan lokasi tempat. Selain itu ukuran volume hippocampus pada tikus jantan ditemukan juga lebih besar daripada volume hippocampus tikus betina yang mana diduga membawa pengaruh pada perbedaan kemampuan spasial. Ketika tanda-tanda landmark dihilangkan atau diacak maka tikus betina kehilangan ingatan spasialnya, sedangkan tikus jantan tidak terpengaruh pada tanda-tanda yang dihilangkan (Gaulin dalam Barkley \& Jacobs, 2007).

Pengkayaan lingkungan adalah faktor dari luar yang juga berperanan pada ingatan spasial. Beberapa dekade terakhir, banyak perhatian telah berfokus pada caracara dimana otak mamalia dapat mengalami perubahan sebagai tanggapan terhadap pengalaman lingkungan. Pengkayaan lingkungan dapat menghasilkan berbagai perubahan morfologi otak di daerah yang penting untuk pembelajaran dan memori, seperti hippocampus dan neokorteks. Pengkayaan lingkungan akan meningkatkan percabangan dendritik, kontak sinaptik dan neurotransmisi, dan ukuran neuron pada neokorteks tikus (Gomez-Pinilla \& Vaynman, 2005; Rossi \& Angelucci, 2006).

Pengkayaan lingkungan pada hewan dapat berupa pemberian rangsangan seperti benda-benda, alat-alat permainan, terowongan, roda berputar, dan interaksi sosial. Kelompok kontrol biasanya berupa menempatkan individu atau hewan tinggal 
secara terisolasi (secara individual dalam kandang tanpa interaksi sosial) atau sosial kontrol (tinggal berkelompok dalam satu kandang tetapi tidak dikenai rangsangan apapun). Penelitian Lambert, Fernandez, \& Frick (2005) dilakukan pada tikus umur 11 minggu dan pengujian perilaku dilakukan pada umur 14 minggu. Kelompok kontrol tinggal secara berkelompok dan tidak mendapat perangsangan apapun. Kelompok ekperimen mendapatkan pengkayaan selama 6 minggu, dan 7 hari/minggu, dan pengujian dilakukan pada sore hari (mencit yang mendapat pengkayaan lingkungan di pagi hari dan diuji dalam sore hari) dengan menggunakan Working Radial Arm Maze (WRAM). Hasilnya adalah terdapat efek utama (main effect) yang signifikan antara perlakuan dengan memori kerja dan tes post-hoc menunjukkan hasil kelompok EX memiliki tingkat kesalahan yang lebih sedikit secara signifikan dibandingkan kelompok kontrol dan kelompok AC. Kelompok EX membuat kesalahan lebih sedikit dibanding kelompok CS. Analisis kesalahan memori referensi, tidak menunjukkan adanya efek utama perlakuan terhadap kesalahan memori referensi. Hasil pengujian Synaptophysin menunjukkan adanya perbedaan Synaptophysin (adanya ikatan kalsium glikoprotein 38$\mathrm{kDa}$ ) pada membran vesikel presinaptik yang berisi neurotransmitter.

Dilaporkan dari pengujian teori Hebb bahwa sekelompok tikus yang dibesarkan di rumah secara bebas sebagai hewan peliharaan, hasil pengujian pada HebbWilliam maze menunjukkan hasil yang lebih baik dibandingkan dengan tikus yang dibesarkan dalam kandang mereka. Sejumlah penelitian yang membandingkan efek lingkungan yang diperkaya dan lingkungan yang miskin, hasil pengujian pembelajaran pada maze menunjukkan temuan yang khas, yang sejalan dengan teori Hebb, bahwa kelompok-kelompok yang tinggal dalam pengkayaan lingkungan memiliki kemampuan problem solving yang unggul. Namun beberapa temuan lainnya menemukan hasil yang tidak konsisten dimana pengkayaan lingkungan tidak memberikan pengaruh terhadap kemampuan problem solving (Gardner, Boitano, Mancino \& D'Ami, 1975).

Penelitian Williams et al.. (2001), ditemukan pengkayaan lingkungan berpengaruh pada peningkatan kinerja dalam tes memori spasial, menginduksi neurogenesis di hippocampus, meningkatkan kelangsungan hidup sel granula yang baru dibentuk, dan menghambat apoptosis spontan. Meskipun neuroplastisitas dari otak mamalia menurun seiring dengan usia, bukti terbaru menunjukkan bahwa otak orang dewasa menunjukkan plastisitas yang signifikan akibat diberikannya pengkayaan lingkungan. Penelitian ini dirancang untuk mengevaluasi pengaruh pengkayaan lingkungan pada memori spasial dan respon pengikatan protein $C R E B(C R E B=c A M P$ respons element binding protein) dari immunoreactivity hippocampus. Subjek 40 ekor mencit C57/BL/6 ras hibrida yang dibagi dalam empat kelompok, yaitu, 10 ekor tinggal secara individual, 11 ekor tinggal dalam satu kandang secara sosial, sembilan ekor usia 35 hari dan mendapat pengkayaan hingga usia 94 hari yang tinggal secara sosial dan mendapat pengkayaan fisik berupa mainan (kontainer, tangga, lorong), dan kelompok keempat terdiri 10 ekor tinggal secara sosial dan mendapat mainan sejak usia 100 hari hingga usia 159 hari. Mainan diberikan pada permulaan malam hari hingga empat jam. Hasil penelitian menunjukkan bahwa pengkayaan lingkungan pada usia 35 hari hingga 94 hari 
meningkatkan kinerja pada morris water maze dan meningkatkan immunoreactivity ke CREB di hippocampus. Tikus tinggal dalam kelompok sosial tanpa mainan tidak menghasilkan perbedaan yang signifikan dalam kinerja navigasi.

Leggio et al. (2005) menemukan bahwa lingkungan yang diperkaya terdiri dari peningkatan kombinasi hubungan sosial, latihan fisik dan interaksi sosial, memunculkan modifikasi perilaku dan perkembangan saraf. Dalam studi ini, peneliti menganalisis efek lingkungan yang kompleks terhadap perilaku pada fungsi spasial, dan arborisasi dendritik dan kepadatan tulang belakang area kortikal terutama yang terlibat dalam belajar spasial pada korteks parietal. Awalnya, terdapat 40 ekor tikus 40 Wistar digunakan dalam percobaan. Namun data yang terkumpul hanya dari 36 ekor tikus; data empat ekor dibuang karena perilaku mereka mogok dalam sesi pertama pada tugas radial maze. Subjek berusia 21 hari, dibagi dalam dua kelompok, yaitu kelompok eksperimen $(\mathrm{N}=17)$ mendapat pengkayaan. Kandang berisi serutan kayu, roda berjalan, rumah-rumahan, mainan plastik berwarna dan tabung kecil. Pada usia 3 bulan, kedua kelompok diuji dalam tugas Radial Arm Maze (RAM) dan Morris Water Maze (MWM). Selain itu juga dilakukan analisis morfologi pada layer-III neuron piramidal dari korteks parietal pada hewan yang dipilih pada kedua kelompok eksperimental. Dalam tugas Radial Arm Maze (RAM), hewan yang diperkaya lingkungannya menunjukkan tingkat kinerja yang lebih tinggi, memiliki ketrampilan prosedural dan memori yang lebih baik

Harburger, Lambert, \& Frick (2007) menguji pengaruh pengkayaan lingkungan dan usia terhadap ingatan spasial pada mencit C57BL/6 jantan. Pengkayaan lingkungan diberikan dalam jangka waktu panjang pada mencit muda ( 3 bulan, $\mathrm{n}=$ $25)$, mencit setengah baya ( 15 bulan, $n=30)$, dan mencit tua ( 21 bulan, $\mathrm{n}=30$ ). Subjek ditempatkan dalam kandang yang berisi 8 ekor per kandang untuk kelompok eksperimen dan 5 ekor per kandang untuk kelompok kontrol. Memori referensi spasial diuji dalam Morris Water Maze (MWM). Hasilnya menunjukkan bahwa pengkayaan selama 24 jam/hari selama kurang lebih 6 minggu secara signifikan meningkatkan memori spasial dalam Morris Water Maze (MWM) pada mencit usia tua, tetapi tidak pada mencit muda dan mencit setengah baya. Hasilnya adalah terdapat efek utama (main effect) pengaruh pengkayaan lingkungan terhadap lama waktu berenang, jarak berenang, dan kecepatan berenang. Pengkayaan mengurangi lama waktu berenang dan jarak berenang, dan meningkatkan kecepatan berenang.

Penelitian-penelitian sebelumnya memadukan pengkayaan lingkungan dengan subjek tikus jantan saja (Harburger, Lambert, \& Frick, 2007; Kumar, Rani, Tchigranova, Lee, \& Foster, 2012; Leger et al., 2012; Veena, Srikumar, Raju, \& Rao, 2009), memadukan pengkayaan lingkungan dengan subjek tikus betina saja (Frick \& Fernandez, 2003), dan memadukan pengkayaan lingkungan dengan subjek tikus jantan dan tikus betina (Bimonte, Hyde, Hoplight, \& Denenberg, 2000; Peña, Prunell, Rotllant, Armario, \& Escorihuela, 2009; Veng, Granholm, \& Rose, 2003).

Berdasarkan kajian-kajian tersebut di atas, diperoleh kesimpulan bahwa jenis kelamin berpengaruh terhadap ingatan spasial, baik disebabkan oleh faktor hormone gonad (hormone sex) maupun faktor otak. Dan faktor eksternal berupa stimulasi dari lingkungan juga dapat berpengaruh 
terhadap ingatan spasial. Penelitian ini bertujuan melihat apakah ada pengaruh jenis kelamin dan pengkayaan lingkungan terhadap ingatan spasial. Hipotesis yang diajukan pada penelitian ini sebagai berikut. Pertama, berdasarkan jarak tempuh berenang: terdapat interaksi antara perlakuan (pengkayaan lingkungan) dengan jenis kelamin terhadap jarak berenang, terdapat pengaruh perlakuan (pengkayaan lingkungan) terhadap ingatan spasial pada aspek jarak berenang, dan terdapat pengaruh jenis kelamin terhadap ingatan spasial pada aspek jarak berenang. Kedua, berdasarkan waktu tempuh berenang: terdapat interaksi antara perlakuan (pengkayaan lingkungan) dengan jenis kelamin terhadap waktu berenang, terdapat pengaruh perlakuan (pengkayaan lingkungan) terhadap ingatan spasial pada aspek waktu berenang, dan terdapat pengaruh jenis kelamin terhadap ingatan spasial pada aspek waktu berenang.

\section{Metode}

Penelitian ini memiliki variabel tergantung yaitu ingatan spasial dan variabel bebas yaitu pengkayaan lingkungan dan jenis kelamin. Ingatan spasial adalah ingatan tikus mencari platform dari titik start hingga menemukan platform dalam sumur Morris Water Maze (MWM) selama maksimal tiga menit. Ingatan spasial dihitung dari jarak berenang menemukan platform dan waktu yang dipakai untuk menemukan platform, yang dinilai secara sendiri-sendiri. Semakin pendek jarak tempuh tikus menemukan platform dan semakin cepat waktu yang dipakai untuk menemukan platform, ingatan spasial semakin baik. Pengukuran ingatan spasial mengikuti prosedur dari Partadiredja dan Bedi (2011).
Pengkayaan lingkungan adalah pemberian stimulasi sosial dan benda mati yang mengikuti disain dari modifikasi penelitian-penelitian sebelumnya, antara lain Me'ndez-Lo' pez, Me'ndez, Lo'pez \& Arias (2009) yang menliti pada subjek jantan dan betina, dan penelitian Leggio et al. (2005) yang menggunakan benda-benda alam sebagai bentuk stimulus benda mati. Terdapat empat variasi pengkayaan lingkungan yang diberikan kepada tikus jantan dan tikus betina, yaitu penempatan tikus tinggal secara kelompok dan diberikan benda-benda mati, penempatan tikus pada kelompok saja, penempatan tikus secara individual dengan diberikan benda-benda mati, dan penempatan secara individual saja. Keempat variasi diberikan kepada kelompok tikus jantan dan kelompok tikus betina. Pemberian benda mati adalah penempatan benda mati yang bervariasi bentuk dan warnanya ke dalam kandang sejumlah 3-4 aitem dalam satu kandang, yang mana setiap aitem benda diganti dua kali dalam satu minggu (pada hari Selasa dan hari Jumat). Pengkayaan lingkungan diberikan selama 60 hari.

Subjek dalam penelitian ini adalah 44 ekor tikus (Rattus novergicus) Wistar, yang terdiri atas 22 ekor tikus Wistar jantan dan 22 ekor tikus Wistar betina, usia umur 22 hari (usia lepas persusuan). Subjek didatangkan dari bagian unit pemeliharaan hewan coba Laboratorium Penelitian dan Pengujian Terpadu (LPPT) UGM. Penelitian dilakukan di Laboratorium Fisiologi di Gedung Radioputro Lantai Lima Fakultas Kedokteran (FK) UGM.

Kandang tikus yang digunakan dalam penelitian ini terdiri atas dua ukuran, yaitu kandang besar $(40 \times 30 \times 12 \mathrm{~cm})$ untuk kelompok pengkayaan sosial, dan kandang kecil (35x25x11 cm) untuk kelompok individu. Tikus diberi pakan berupa AD II (Japfa Comfeed) dengan kandungan: kadar 
air maksimal $12 \%$, protein kasar minimal $15 \%$, lemak kasar 3-7\%, serat kasar maksimal 6\%, abu maksimal 7\%, kalsium $0,9-1,1 \%$, fosfor $0,6-0,9 \%$. Stimulasi benda mati menggunakan barang-barang berupa: kertas tisu, terowongan dari kertas karton, daun kering, cincin dari bahan rotan, bola plastik, ranting, bola dari kertas HVS, benang woll, kerang, bola kayu, balok kayu, bola dari kain, puzzle warna warni dari kayu, koin, dan perosotan kayu. Protokol eksperimen dijalankan dalam Morris water maze, yaitu kolam berupa tangki sirkuler, diameter $1,5 \mathrm{~m}$, tinggi $0,45 \mathrm{~m}$.

\section{Desain eksperimen}

Dalam penelitian ini, desain eksperimen lebih kepada eksperimental murni dengan rancangan post test only control group design. Bentuk ini adalah untuk menguji pengaruh pengkayaan lingkungan terhadap ingatan spasial. Pengujian hipotesis dalam penelitian ini merujuk kepada kesan pengkayaan lingkungan terhadap ingatan spasial yang diukur berdasar jarak renang dan waktu renang, pada fase belajar (Escape Acquisition Test) dan fase belajar (Memory Persistence Test). Notasi desain eksperimen dapat dilihat pada Tabel 1, dan pembagian subjek penelitian dalam kelompok terlihat pada Tabel 2.

Setelah fase habituasi ruang laboratorium, tikus mendapatkan pengkayaan lingkungan yaitu tikus ditempatkan dalam kelompoknya masing-masing secara acak. Tikus yang mendapat stimulasi sosial dan benda mati tinggal bersama dua ekor tikus lain dan mendapat benda-benda di dalam kandang. Tikus yang tidak mendapat stimulasi sosial akan tinggal secara individual dalam satu kandang. Tikus yang mendapatkan stimulasi benda mati akan bersama tiga hingga empat item benda sebagai simulasi secara visual dan taktil yang diletakkan dalam sangkar. Cara penempatan benda mati ialah dengan meletakkan 3 hingga 4 jenis benda secara sekaligus ke dalam kandang. Pemberian benda-benda ini dilakukan sesuai dengan jadwal. Stimulasi ini diganti pada waktu sore hari ketika memeriksa kesehatan tikus, memberi makanan dan minuman. Stimulasi ini diletakkan oleh dua orang asisten peneliti, dengan orang yang sama. Hal ini dilakukan supaya tikus tidak terganggu oleh banyak orang agar tidak memengaruhi keadaan psikisnya.

Tabel 1.

Notasi desain eksperimen

\begin{tabular}{|c|c|c|c|c|c|c|c|}
\hline \multicolumn{4}{|c|}{ Kelompok Jantan } & \multicolumn{4}{|c|}{ Kelompok Betina } \\
\hline $\mathrm{R}$ & K 1 & $\mathrm{X}_{\mathrm{A} 1}$ & $\mathrm{O} 1, \mathrm{O} 2, \mathrm{O} 3, \ldots \mathrm{O} 27$ & & K 5 & $\mathrm{X}_{\mathrm{A} 1}$ & $\mathrm{O} 1, \mathrm{O} 2, \mathrm{O} 3, \ldots \mathrm{O} 27$ \\
\hline $\mathrm{R}$ & $\mathrm{K} 2$ & $\mathrm{X}_{\mathrm{A} 2}$ & $\mathrm{O} 1, \mathrm{O} 2, \mathrm{O} 3, \ldots \mathrm{O} 27$ & $\mathrm{R}$ & K 6 & $\mathrm{X}_{\mathrm{A} 2}$ & $\mathrm{O} 1, \mathrm{O} 2, \mathrm{O} 3, \ldots \mathrm{O} 27$ \\
\hline $\mathrm{R}$ & K 3 & $\mathrm{X}_{\mathrm{B} 1}$ & $\mathrm{O} 1, \mathrm{O} 2, \mathrm{O} 3, \ldots \mathrm{O} 27$ & $\mathrm{R}$ & K 7 & $\mathrm{X}_{\mathrm{B} 1}$ & $\mathrm{O} 1, \mathrm{O} 2, \mathrm{O} 3, \ldots \mathrm{O} 27$ \\
\hline $\mathrm{R}$ & K 4 & $\mathrm{X}_{\mathrm{B} 2}$ & $\mathrm{O} 1, \mathrm{O} 2, \mathrm{O} 3, \ldots \mathrm{O} 27$ & $\mathrm{R}$ & K 8 & $\mathrm{X}_{\mathrm{B} 2}$ & $\mathrm{O} 1, \mathrm{O} 2, \mathrm{O} 3, \ldots \mathrm{O} 27$ \\
\hline
\end{tabular}

Keterangan: K: Kode kelompok. $\mathrm{X}_{\mathrm{A} 1}$ : Perlakuan 1 (tinggal dalam kelompok dan dengan stimulasi benda mati). $\mathrm{X}_{\mathrm{A} 2}$ : Perlakuan 2 (tinggal dalam kelompok tanpa stimulasi benda mati). $\mathrm{X}_{\mathrm{B} 1}$ : Perlakuan 3 (tinggal secara individual tetapi ada benda mati). $\mathrm{X}_{\mathrm{B} 2}$ : Perlakuan 4 (tinggal tanpa stimulasi sosial dan tanpa benda mati). O1, O2, O3 sd O27: Post test (trial ke-1, trial ke-2, trial ke-3, ... trial ke-27).

Proses Pemberian Manipulasi (Pengkayaan Lingkungan) 
Tabel 2.

Pembagian subjek dalam kelompok

\begin{tabular}{cccccccc}
\hline & $\begin{array}{c}\text { Jumlah tikus } \\
\text { per kandang }\end{array}$ & $\begin{array}{c}\text { Stimulasi } \\
\text { Benda Mati }\end{array}$ & N & & $\begin{array}{c}\text { Jumlah Tikus } \\
\text { Per Kandang }\end{array}$ & $\begin{array}{c}\text { Stimulasi } \\
\text { Benda Mati }\end{array}$ & N \\
\hline K 1 & 3 & YA & 6 & K 5 & 3 & YA & 6 \\
K 2 & 3 & TDK & 6 & K 6 & 3 & TDK & 6 \\
K 3 & 1 & YA & 5 & K 7 & 1 & YA & 5 \\
K 4 & 1 & TDK & 5 & K 8 & 1 & TDK & 5 \\
\hline
\end{tabular}

Protokol pengambilan data dengan Morris Water Maze (MWM)

Morris Water Maze (MWM) merupakan apparatus berupa tangki sirkuler, diameter 1,5 $\mathrm{m}$ dan tinggi $0,45 \mathrm{~m}$. Tangki diisi air keruh yang dibuat dari air santan kelapa, tinggi air adalah 0,18 m. Temperatur air kira-kira $23^{\circ} \mathrm{C}$. Sebuat platform sirkuler terbuat dari kontainer kaleng yang dicat putih berdiameter $13 \mathrm{~cm}$ dan tinggi $16,5 \mathrm{~cm}$ diletakkan $2,5 \mathrm{~cm}$ di bawah tinggi air kolam. Kolam dibagi menjadi empat kuadran dan diberi tanda. Dua titik start ditandai pada dinding masing-masing kuadran. Semua titik start dipisahkan dengan jarak yang sama, sehingga terdapat delapan titik start di sekeliling kolam. Platform diposisikan secara acak di tengah salah satu kuadran. Tes ingatan spasial dengan Morris Water Maze (MWM) dilakukan dengan protokol yang dilakukan oleh Partadiredja dan Bedi (2011), yaitu: Pertama, Escape Acquisition Test (EAT). EAT atau tes penyelamatan diri adalah tes yang dilakukan selama fase penyelamatan diri yaitu fase belajar (latihan) sebagai proses pembelajaran untuk pembentukan ingatan spasial. Fase ini dilakukan dalam tiga hari berturut-turut dengan delapan latihan per hari, sehingga jumlah keseluruhan latihan selama fase penyelamatan diri adalah 24 latihan (latihan 1-8 pada hari pertama, latihan 9-16 pada hari kedua, dan latihan 17-24 pada hari ketiga). Dari setiap tes atau latihan, dikumpulkan data waktu latensi (detik) dan jarak (panjang) lintasan (cm). Data panjang lintasan didapatkan dari pengukuran panjang lintasan yang ditempuh tikus pada skala yang didapatkan dari perbandingan diameter kolam MWM dengan diameter kolam MWM yang sesungguhnya. Sebelum tes dimulai, dipilih satu nomor antara 1-8 secara acak sebagai nomor starting point (titik start) bagi masing-masing tes untuk setiap tikus. Selain mengacak nomor starting point juga dilakukan pengacakan kuadran dimana platform akan diletakkan. Tes dimulai dengan meletakkan tikus di titik start dengan kepala menghadap dinding kolam. Tikus dibiarkan berenang sampai menemukan dan naik di atas platform yang disembunyikan dua $\mathrm{cm}$ di bawah permukaan air. Naiknya tikus di atas platform menandai berakhirnya tes. Waktu yang diperlukan tikus untuk mencapai platform dicatat sebagai waktu latensi. Jika seekor tikus gagal menemukan platform dalam 180 detik, waktu latensi dicatat 180 detik. Setiap tikus menjalani 8 kali tes per hari selama tiga hari berturut-turut.

Kedua, Memory Persistence Test (MPT). MPT atau tes persistensi ingatan dilakukan dua kali. Tes persistensi ingatan yang pertama dilakukan pada tujuh hari setelah tes penyelamatan diri. Tes persistensi ingatan yang kedua dilakukan pada 14 hari setelah tes penyelematan diri. Sebelum tes dimulai, nomor titik start dipilih lagi secara acak untuk tiap tikus. Tes dimulai dengan 
meletakkan tikus di titik start dengan kepala menghadap dinding kolam. Tikus dibiarkan berenang sampai menemukan dan naik di atas platform tersembunyi yang ditempatkan di tempat yang sama dengan tes sebelumnya (tes penyelamatan diri) untuk tiap tikus. Waktu persistensi dicatat untuk setiap tes. Jika seekor tikus gagal menemukan platform dalam 180 detik, waktu persistensi 180 detik. Tes hanya dilakukan sekali untuk tiap tikus.

\section{Hasil}

Data yang diperoleh dari delapan kelompok subjek yang diukur ingatan spasialnya berdasarkan jarak berenang dan lama waktu berenang pada fase belajar (EAT) dan fase mengingat (MPT), dianalisis dengan SPANOVA (Split-plot Anova Design atau ANOVA Mixed Design), yaitu gabungan antara between-wthin subjects ANOVA. Selain itu untuk melihat tingkat kesehatan tikus dilakukan pengukuran berat badan dimulai dari masuk laboratorium hingga pengukuran memori spasial. Tingkat kesehatan dan berat badan tikus dapat dilihat pada Tabel 3.

Pengujian hipotesis menunjukkan beberapa hasil sebagai berikut. Berdasarkan uji repeated-measures MANOVA pada jarak berenang, ditemukan: pertama, tidak terdapat interaksi antara perlakuan (pengkayaan lingkungan) dengan jenis kelamin, $F(3,36)=0,478, p=0,700(p>$ 0,05). Kedua, tidak terdapat pengaruh perlakuan terhadap ingatan spasial pada aspek jarak berenang, $\mathrm{F}(3,36)=1,256, \mathrm{p}=$ $0,304(\mathrm{p}>0,05)$. Ketiga, terdapat pengaruh jenis kelamin terhadap ingatan spasial pada aspek jarak berenang, $F(1,36)=$ $15,912, p=0,000(p<0,001)$. Hasil pengujian hipotesis 1 sampai dengan 3 , dapat dilihat pada Tabel 4.

Berdasarkan uji repeated-measures MANOVA pada waktu berenang, ditemukan beberapa hal. Pertama, tidak terdapat interaksi antara perlakuan (pengkayaan lingkungan) dengan jenis kelamin, $\mathrm{F}(3,36)$ $=0,232, \mathrm{p}=0,874(\mathrm{p}>0,05)$. Kedua, tidak terdapat pengaruh perlakuan terhadap ingatan spasial pada aspek waktu berenang, $F(3,36)=0,174 p=0,913(p>$ $0,05)$. Ketiga, terdapat pengaruh jenis kelamin terhadap ingatan spasial pada aspek waktu berenang, $F(1,36)=14,424, p$ $=0,000(p<0,001)$. Hasil pengujian hipotesis 4 sampai dengan 6 , dapat dilihat pada Tabel 5.

Tabel 3.

Rerata berat badan tikus saat masuk dan saat pengambilan data MWM

(Hr1-Hr2-Hr3: Latensi, Hr4 - Hr5: Persistensi)

\begin{tabular}{lrrrrrrrr}
\hline \multicolumn{1}{c}{ Berat Badan } & \multicolumn{1}{c}{ K1 } & \multicolumn{1}{c}{ K2 } & \multicolumn{1}{c}{ K3 } & \multicolumn{1}{c}{ K4 } & \multicolumn{1}{c}{ K5 } & \multicolumn{1}{c}{ K6 } & \multicolumn{1}{c}{ K7 } & \multicolumn{1}{c}{ K8 } \\
\hline Masuk Lab & 44,17 & 48,33 & 44,00 & 42,00 & 36,67 & 35,83 & 37,00 & 42,00 \\
Hari 1 MWM & 304,17 & 306,67 & 317,00 & 291,00 & 191,67 & 176,67 & 190,00 & 206,00 \\
Hari 2 MWM & 304,17 & 306,67 & 317,00 & 291,00 & 191,67 & 176,67 & 190,00 & 206,00 \\
Hari 3 MWM & 314,17 & 306,67 & 326,00 & 309,00 & 200,83 & 175,00 & 195,00 & 209,00 \\
Hari 10 MWM & 334,17 & 325,00 & 342,00 & 316,00 & 191,67 & 179,17 & 195,00 & 217,00 \\
Hari 17 MWM & 343,33 & 343,33 & 354,00 & 329,00 & 205,83 & 175,83 & 199,00 & 211,00 \\
\hline
\end{tabular}

K1: Jantan sosial \& benda mati, K2: Jantan sosial, K3: Jantan individual \& benda mati, K4: Jantan individual, K5: Betina sosial \& Benda mati, K6: Betina sosial, K7: Betina individual \& benda mati, K8: Betina individual 
Tabel 4.

Hasil repeated-measures MANOVA jarak berenang dari jenis kelamin dan pengkayaan lingkungan

\begin{tabular}{llllll}
\hline \multicolumn{1}{c}{ Sumber } & \multicolumn{1}{c}{ JK } & df & RK & F & p \\
\hline Jenis Kelamin & 216212,147 & 1 & 216212,147 & 15,912 & $0,000^{*}$ \\
Pengkayaan Lingkungan & 51215,754 & 3 & 17071,918 & 1,256 & 0,304 \\
Jenis Kelamin*Pengkayaan Lingkungan & 19483,728 & 3 & 6494,576 & 0,478 & 0,700 \\
\hline $\mathrm{p}<0,001$ & & & & &
\end{tabular}

Tabel 5.

Hasil repeated-measures MANOVA waktu berenang dari jenis kelamin dan pengkayaan lingkungan

\begin{tabular}{lccccc}
\hline \multicolumn{1}{c}{ Sumber } & JK & Df & RK & F & p \\
\hline Jenis Kelamin & 46321,292 & 1 & 46321,292 & 14,424 & $0,001^{*}$ \\
Pengkayaan Lingkungan & 1679,547 & 3 & 559,849 & 0,174 & 0,913 \\
Jenis Kelamin*Pengkayaan Lingkungan & 2231,554 & 3 & 743,851 & 0,232 & 0,874 \\
\hline
\end{tabular}

${ }^{*} \mathrm{p}<0,001$

\section{Diskusi}

Hasil analisis menunjukkan tidak ada interaksi antara perlakuan (pengkayaan lingkungan) dan jenis kelamin dengan ingatan spasial baik pada aspek jarak berenang maupun waktu berenang. Pemberian perlakuan berupa perpaduan antara pengkayaan lingkungan dan jenis kelamin tidak berpengaruh terhadap ingatan spasial. Jenis kelamin berperan secara signifikan terhadap ingatan spasial. Tikus jantan, baik yang mendapat pengkayaan maupun tidak mendapat pengkayaan, memiliki ingatan spasial yang lebih baik daripada tikus betina, baik pada aspek jarak berenang maupun pada aspek waktu berenang.

Adanya pengaruh jenis kelamin terhadap ingatan spasial dirangkum dalam penelitian Barkley \& Jacobs (2007) yang menemukan bahwa jenis kelamin dan spesies berbeda dalam kemampuan mengingat spasial. Gaulin (Barkley \& Jacobs, 2007) yang meneliti pertama kali pada 1986 menemukan bahwa hewan jantan dari spesies polygynous ternyata lebih sukses dalam reproduksinya dibanding hewan jantan dari spesies monogamous, hal ini disebabkan karena pejantan polygynous memiliki kemampuan mencari jejak hewan betina dan memiliki pola navigasi spasial yang bagus dalam menemukan pasangannya. Cimadevilla (Barkley\& Jacobs, 2007) menemukan bahwa tikus betina lebih lambat daripada tikus jantan dalam tugas penyelesaian masalah berupa mencari lokasi platform pada sumur Morris Water Maze. Hal ini bisa disebabkan karena besar dan kekuatan otot-otot pada tikus jantan lebih besar dan kuat daripada otot-otot tikus betina. Besar dan kekuatan otot tikus jantan dapat dilihat dari lebih besarnya berat badan tikus atau dari massa otot tikus jantan dibanding tikus betina. Pada penelitian ini berat badan tikus jantan dan tikus betina tampak pada Tabel 3 dimana berat badan tikus jantan pada semua kelompok lebih besar daripada berat badan tikus betina. Harris, D'Eath, \& Healy (2008) juga menemukan bahwa perbedaan jenis kelaminlah yang berperan terhadap perbedaan kemampuan mengingat spasial pada tikus, dan bukan karena faktor pengkayaan lingkungan 
yaitu tinggal secara terisolasi atau sosial. Tikus jantan memiliki otak yang berbeda secara morfologi dan fisiologi dibandingkan otak tikus betina sehingga berpengaruh terhadap kemampuan spasial.

Penelitian ini menunjukkan hasil yang tidak signifikan seperti hanya beberapa temuan penelitian sebelumnya, dimana sejumlah penelitian yang membandingkan efek lingkungan yang diperkaya dan lingkungan yang miskin hasil pengujian pembelajaran pada maze menunjukkan temuan yang khas, yang sejalan dengan teori Hebb bahwa kelompok-kelompok yang tinggal dalam pengkayaan lingkungan memiliki kemampuan problem solving yang unggul. Namun beberapa temuan lainnya menemukan hasil yang tidak konsisten dimana pengkayaan lingkungan tidak memberikan pengaruh terhadap kemampuan problem solving (Gardner et al., 1975).

Tidak terbuktinya pengaruh pengkayaan lingkungan terhadap ingatan spasial dapat dijelaskan antara lain jenis benda yang dipergunakan untuk stimulus benda mati pada penelitian ini hanya menyebabkan rangsangan sensorik saja dan tidak menempatkan roda berjalan sebagai salah satu item yang dapat merangsang area motorik. Roda berjalan berperan untuk merangsang motorik dan tidak hanya merangsang sensorik saja. Lambert et al. (2005), menemukan berjalan pada roda berjalan berdiameter $11,5 \mathrm{~cm}$ yang ditempatkan pada kandang memicu pergerakan motorik yang dapat meningkatkan kemampuan memori sedangkan latihan akrobat dengan cara berjalan melintasi jembatan yang menghubungkan dua sisi, tidak berperanan terhadap ingatan spasial. Hal ini terkait dengan gerakan motorik dapat membantu membentuk mnemonic dan meningkatkan percabangan sinaptik pada hipokampus, sedangkan latihan akrobat dan stimulasi kognitif lebih berperan pada percabangan sinaptik di area neokorteks, area yang tidak terkait dengan ingatan spasial. Penelitian Ekstrand, Hellsten, \& Tingström (2008) juga menemukan pengaruh yang signifikan adanya gerakan berlari (exercise) naik turun tangga berpengaruh terhadap angiogenesis di hipokampus dan ingatan spasial pada tikus yang mengalami stress. Temuan ini menunjukkan bahwa jenis pengkayaan lingkungan yang berbeda memicu pengaruh yang berbeda pula terhadap ingatan spasial.

\section{Kesimpulan}

Ingatan spasial adalah ingatan terkait dengan kemampuan menemukan suatu lokasi, membaca peta, navigasi dan melihat ruang bidang. Spesies berjenis kelamin jantan memiliki kemampuan spasial yang lebih baik daripada spesies berjenis kelamin betina, karena spesies jantan terbiasa untuk lebih banyak aktif di luar, mencari makan, mencari pasangan, menghadapi musuh atau berperang, dan bekerja di luar rumah, yang secara evolusioner masih bertahan. Spesies betina lebih banyak berada di rumah, mengandung, melahirkan dan merawat anak, serta melindungi anak. Perbedaan kebiasaan ini menyebabkan jantan atau pria lebih banyak mengeksplorasi ruang, menjelajah, dan menemukan tempat atau lokasi. Faktor eksternal misalnya gaya hidup, paparan stimulasi lingkungan tidak berpengaruh untuk dapat mengubah kemampuan betina meningkatkan ingatan spasialnya. Pada penelitian ini pengkayaan lingkungan dengan memberikan stimulasi sosial dan benda mati selama 60 hari tidak berpengaruh terhadap ingatan spasial. Jenis pemberian stimulasi berupa tinggal secara bersama sebanyak 3 ekor tikus dan 
pemberian benda-benda mati dalam bentuk natural, tidak berperan membedakan ingatan spasial pada semua kelompok. Hal ini bisa jadi karena jenis stimulasi, luas kandang serta kepadatan lingkungan tidak mampu mempengaruhi ingatan spasial. Selain itu, pengukuran ingatan spasial sebanyak 24 kali pada fase belajar dan tiga kali pada fase mengingat tidak menunjukkan perbedaan mengingat spasial. Pada penelitian ini, hanya jenis kelamin saja yang berpengaruh terhadap ingatan spasial.

\section{Saran}

Penelitian selanjutnya dapat dilakukan dengan menempatkan roda berjalan (running wheel) untuk mestimulasi kemampuan motorik, menggunakan subjek tikus dengan tingkat usia yang berbeda, menambahkan aspek yang lain misalnya stress, mempertimbangkan faktor hormon pada tikus betina misalnya kadar estrogen yang juga berperan pada ingatan spasial, merekam secara visual aktivitas tikus di sumur MWM misalnya thigmotaxis (gerakan menjauhi objek/platform), mencatat secara akurat pergerakan tikus dengan menggunakan rekaman audio visual yang reliabel, dan selalu mengontrol suhu air dalam MWM.

\section{Kepustakaan}

Barkley, C. L., \& Jacobs, L. F. (2007). Sex and species differences in spatial memory in food-storing kangaroo rats. Animal Behaviour, 73, 321-329 doi: 10. 1016/ j.anbehav.2006.07.009.

Baxendale, S. A., Thompson, P. J., \& Paesschen, W. P. (1998). A test of spatial memory and its clinical utility in the pre-surgical investigation of temporal lobe epilepsy patients. Neuropsychologia, 36, 37, $591-602$.
Bimonte, H. A., Hydea, L. A., Hoplighta, B. J., \& Denenberga, V. H. (2000). In two species, females exhibit superior working memory and inferior reference memory on the water radialarm maze. Physiology \& Behavior, 70, 311-317.

Chalfonte, B. L., Verfaellie, M., Johnson, M. K., \& Reiss, L. (1996). Spatial location memory in amnesia: Binding item and location information under incidental and intentional encoding conditions. Memory, 4, 591-614. doi: 10.1080/ 7419 40998

Dale, R. H. I. (1987). Similarities between human and animal spatial memory: Item and order information. Animal Learning \& Behaviour, 15(3), 293-300.

Ekstrand, J, Hellsten, J., \& Tingström, A. (2008). Environmental enrichment, exercise and corticosterone affect endothelial cell proliferation in adult rat hippocampus and prefrontal cortex. Neuroscience Letters, 442, 203-207. doi: 10.1016/j.neulet.2008.06.085

Frick, K. M., \& Fernandez, S. M. (2005). Enrichment enhances spatial memory and increases synaptophysin levels in aged female mice. Neurobiology of Aging, 24 , 615-626.

Gardner, E. B., Boitano, J. J., Mancino, N. S., \& D'Ami, D. P. (1975). Environmental enrichment and deprivation: Effects on learning, memory and exploration. Physiology and Behavior, 14, 321-327.

Gomez-Pinilla, F., \& Vaynman, S. (2005). A "deficient environment" in prenatal life may compromise systems important for cognitive function by affecting BDNF in the hippocampus. Experimental Neurology, 192, 235-243. doi: 10.1016/j.expneurol.2004.12.001

Guyton, A. C. \& Hall, J. E. (2001). Buku ajar fisiologi kedokteran. Jakarta: EGC 
Harburger, L. L., Lambert, T. J., \& Frick, K. M. (2007). Age-dependent effects of environmental enrichment on spatial reference memory in male mice. Behavioural Brain Research, 185, 43-48. doi: 10.1016/j.bbr.2007.07.009

Harris, A. P., D'Eath, R. B., \& Healy, S. D. (2008). Sex differences in spatial cognition are not caused by isolation housing. Behaviour, 145, 757-778. doi: $10.1163 / 156853908783929142$

Kumar, A., Rani, A., Tchigranova, O., Lee, W., \& Foster, T.C. (2012). Influence of late-life exposure to environmental enrichment or exercise on hippocampal function and CA1 senescent physiology. Neurobiology of Aging, 33, 828.e1- 828.e17. doi: 10.1016/ j.neurobiolaging.2011.06.023

Lambert, T. J.; Fernandez, S. M., \& Frick, K. M. (2005). Different types of environmental enrichment have discrepant effects on spatial memory and synaptophysin levels in female mice. Neurobiology of Learning and Memory, 83, 206-216. doi: 10.1016/ j.nlm.2004.12.001

Leger, M., Bouet, V., Freret, T., Darmaillacq, A., Dacher, M., Dauphin, F., Boulouard, M., \& Schumann-Bard, P. (2012). Environmental enrichment improves recent but not remote memory in association with a modified brain metabolic activation profile in adult mice. Behavioural Brain Research, 228, 22- 29. doi: 10.1016/ j.bbr. 2011.11.022

Leggio, M. G., Mandolesi, L., Federico, F., Spirito, F., Ricci, B., Gelfo, F., \& Petrosini, L. (2005). Environmental enrichment promotes improved spatial abilities and enhanced dendritic growth in the rat. Behavioural Brain
Research, 163, 78-90. doi: 10.1016/ j.bbr. 2005.04.009

Me'ndez-Lo' pez, M., Me'ndez, M., Lo'pez, L., \& Arias, J. L. (2009). Spatial working memory learning in young male and female rats: involvement of different limbic system regions revealed by cytochrome oxidase activity. Neuroscience Research, 65, 28-34. doi: 10. 1016/j.neures.2009.05.001

O'Keefe, J. \& Nadel, L. (1980). The hippocampus as a cognitive map. Review by: Aryeh Routtenberg. The American Journal of Psychology, 93(1), 177-178.

Partadiredja, G. \& Bedi, K. S. (2011). Mice undernourished before, but not after, weaning perform better in motor coordination and spatial learning task than well-fed controls. Nutritional Neuroscience, 14(4), 129-137, doi: 10. 1179/147683011X12611460764165.

Peña, Y., Prunell, M., Rotllant, D., Armario, A., \& Escorihuela, R.M. (2009). Enduring effects of environmental enrichment from weaning to adulthood on pituitary-adrenal function, pre-pulse inhibition and learning in male and female rats. Psychoneuroendocrinology, 34, 13901404. doi: 10.1016/j.psyneuen. 2009. 04.019

Pinel, J. P. J. (2009). Stres dan kesehatan dalam: Biopsikologi edisi ke-7. Yogyakarta: Pustaka Pelajar.

Rossi, C., Angelucci, A., Constantin, L., Braschi, C., \& Mazzantini, M. (2006). Brain-derived neurotrophic factor (BDNF) is required for the enhancement of hippocampal neurogenesis following environmental enrichment. Europe Journal of Neuroscience, 24, 18501856. doi: 10.1111/j.1460-9568. 2006. 05059.x 
Veena, J., Srikumar, B. N., Raju, T. R., \& Rao, B. S. S. (2009). Exposure to enriched environment restores the survival and differentiation of new born cells in the hippocampus and ameliorates depressive symptoms in chronically stressed rats. Neuroscience Letters, 455, 178-182.

Veng, L. M., Granholm, L. C., \& Rose, G. M. (2003). Age-related sex differences in spatial learning and basal forebrain cholinergic neurons in F344 rats. Physiology \& Behavior, 80, 27- 36.
Williams, B. M., Luo, Y., Ward, C., Redd, K., Gibson, R., Kuczaja, S. A., \& McCoy, J. G. (2001). Environmental enrichment: Effects on spatial memory and hippocampal CREB immunoreactivity. Physiology Behaviour, 73(4), 649-658.

Ziegler, S. G., \& Thornton, J. E. (2010). Low luteinizing hormone enhances spatial memory and has protective effects on memory loss in rats. Hormones and Behaviour, 58, 705-713. doi: 10.1016/ j.yhbeh.2010.07.002

(i) Penelitian ini terselenggara atas dana Hibah Fakultas Psikologi Universitas Gadjah Mada.

(ii) Peneliti mengucapkan terima kasih kepada dr. Ginus Partadiredja, M.Sc., Ph.D. yang telah memperkenalkan dan mendorong untuk melakukan riset dengan subjek hewan, kepada Nur Afifah, Nimas P. Puspapandari, Shiva Ayu Sintani, Rima Mustafa, Ardityo Reyhan, Muchlis Noor, Mutia Nur Kartika Rahmah, Praja Setiawati, Nadya Anjani, Iffah Fitri, Pia Rizki, Luftia Nur Syarifah, Dessy Nooriani, Atna Ryan, Aisyah Chandra Asri, dan Pak Suparno yang telah membantu dalam pengambilan data. 